\title{
Pembuat Nol sebagai Hambatan Didaktis dalam Pertidaksamaan Kuadrat
}

\author{
Kimura Patar Tamba ${ }^{1 *}$, Meiva Marthaulina Lestari ${ }^{2}$ \\ ${ }^{1}$ Pendidikan Matematika, Universitas Pelita Harapan, Tangerang, Indonesia; \\ *kimura.tamba@uph.edu \\ ${ }^{2}$ Pendidikan Matematika, Universitas Timor, Kefamenanu, Indonesia; \\ meivamarthaulina@gmail.com
}

Info Artikel: Dikirim: 20 Juli 2020 ; Direvisi: 11 September 2020; Diterima: 21 September 2020 Cara sitasi: Tamba, K. P., \& Lestari, M. M. (2020). Pembuat Nol sebagai Hambatan Didaktis dalam Pertidaksamaan Kuadrat. JNPM (Jurnal Nasional Pendidikan Matematika), 4(2), 292-307.

\begin{abstract}
Abstrak. Penelitian ini bertujuan untuk menganalisis hambatan didaktis pada pertidaksamaan kuadrat. Pilihan didaktis sering didasarkan pada intuisi guru akan kompleksitas dan ketidaklengkapan informasi akan sebuah pendekatan. Melalui analisis didactical obstacles, guru dapat menghindari atau setidaknya berhati-hati pada suatu pendekatan yang terlihat sederhana dan mudah, tetapi menuntun pada terjadinya hambatan belajar. Penelitian menggunakan pendekatan kualitatif dengan paradigma interpretif dalam kerangka penelitian desain didaktis. Penelitian dilakukan pada 105 siswa kelas IX dan satu orang guru pada salah satu Sekolah Menengah Atas di Bandung. Pengumpulan data dilakukan melalui soal tes pertidaksamaan kuadrat, analisis buku pegangan guru, wawancara siswa dan guru. Hasil pekerjaan siswa atas soal pertidaksamaan kuadrat dianalisis untuk melihat cara mengetahui siswa dan pemahaman siswa. Cara mengetahui ini akan dibandingkan dengan pilihan didaktis yang digunakan guru. Hasil penelitian menunjukkan terdapat didactical obstacles dalam pertidaksamaan kuadrat. Hambatan didaktis tersebut adalah penggunaan metafora pembuat nol sebagai konsep utama dalam penyelesaian pertidaksamaan kuadrat. Pembuat nol ini merupakan implikasi dari penggunaan pendekatan sign chart. Untuk itu guru perlu berhati-hati menggunakan pendekatan garis bilangan dan metafora pembuat nol sebagai pilihan pendekatan didaktis. Penggunaan pendekatan dengan lintasan belajar yang dimulai dari pendekatan fungsi, dapat dipertimbangkan guru dalam pembelajaran pertidaksamaan kudarat.
\end{abstract}

Kata Kunci: Pembuat Nol, Hambatan Didaktis, Pertidaksamaan Kuadrat.

Abstract. This study aims to analyze the obstacles in quadratic inequality. Didactic choices are often based on the teacher's intuition of the complexity and incompleteness of an approach. By analyzing didactical obstacles, teachers can avoid or at least be careful with an approach that looks simple and easy, but leads to learning obstacles. The study used a qualitative approach with an interpretive paradigm within a didactic design research framework. The study was conducted on 
105-grade ninth students and one teacher at a high school in Bandung. Data was carried out through quadratic inequality questions, teacher handbook analysis, student and teacher interviews. The students' work results on the quadratic inequality questions were analyzed to see the students' ways of knowing and students' understanding. Ways of understanding will be compared with the didactic choices the teacher uses. The results show that there are salient obstacles in quadratic inequality. The didactic obstacle is using the metaphor of making zero as the main concept in solving quadratic inequalities. This zero maker is an implication of using the sign chart approach. For this reason, the teacher needs to be careful about using the number line approach and the metaphor for making zero as a didactic approach. The use of an approach with a learning trajectory that starts from a functional approach can be considered by the teacher in learning equality of equality.

Keywords: Zero-Product, Didactical Obstacles, Quadratic Inequality.

\section{Pendahuluan}

Baik dalam hal posisinya pada matematika maupun secara kurikulum pembelajaran, misalnya kurikulum NCTM (global) maupun Kurikulum 2013 (dalam konteks Indonesia), pertidaksamaan kuadrat merupakan topik krusial (Tsamir \& Almog, 2001; Bazzini \& Tsmari, 2001; Bicer, Capraro \& Capraro, 2014; NCTM, 2000; BNSP, 2016). Faktanya urgensi topik ini, tidak diikuti dengan tingkat penguasaan siswa yang baik. Berbagai hasil penelitian memaparkan adanya kesulitan-kesulitan yang dialami siswa dalam menyelesaikan masalah yang berhubungan dengan pertidaksamaan kuadrat (Tsamir \& Bazzini, 2004; Yin, 2005; Ureyen, Mahir \& Cetin, 2006; Almog \& Ilany, 2012).

Berbagai hasil penelitian menawarkan pendekatan-pendekatan didaktis yang harus digunakan guru dalam mengajarkan pertidaksamaan kuadrat. Pendekatan-pendekatan tersebut adalah metode diagram garis bilangan (signchart) (McLaurin, 1985; Dobbs \& Peterson, 1991), pendekatan fungsi (Kieran, 2004), logical connectives (Tsamir dan Reshef, 2006) dan spreadsheet modelling (Abramovich, 2005). Setiap guru dan peneliti memiliki preferensi yang berbeda-beda mengenai pendekatan tersebut. Misalnya, Sackur (2004) yang mengatakan bahwa dengan menggunakan pendekatan fungsi, siswa akan mengalami kesulitan ketika melakukan konversi. Linchevski \& Sfard (1991) mengungkapkan bahwa metode logical connetive lebih problematik bagi siswa karena dituntun untuk langsung berpikir abstrak. Sementara Kieran (2004) menunjukkan bahwa pemahaman anak hanya sebatas prosedural ketika menggunakan pendekatan diagram garis bilangan.

Perbedaan preferensi tersebut didasarkan pada kesulitan yang dialami siswa ketika menggunakan pendekatan tertentu. Kesulitan ini dimaknai sebagai 
sesuatu yang terjadi karena kompleksitas prosedur dan ketidaklengkapan informasi pada suatu pendekatan. Implikasinya akan terjadi kesalahan ketika pendekatan tersebut digunakan siswa meskipun pilihan pendekatan yang digunakan guru terlihat sederhana dan mudah.

Kesalahan sering terjadi karena pengetahuan awal siswa yang tepat pada konteks tertentu tetapi tidak tepat pada konteks lain (Brousseau, 2002). Gagasan ini disebut dengan obstacles. Ada tiga jenis obstacles yaitu hambatan ontogenis (ontogenical obstacles), hambatan didaktis (didactical obstacles) dan hambatan epistemologis (epistemological obstacles). Hambatan yang terbentuk akibat pilihan pendekatan didaktis guru disebut hambatan didaktis. Pilihan didaktis yang sering dianggap guru sederhana dapat membentuk ways of knowing siswa yang parsial bahkan tidak bersesuai dengan struktur pengetahuan pertidaksamaan kuadrat. Oleh karena itu, preferensi atas sebuah pendekatan didaktis, khususnya dalam pertidaksamaan kuadrat, tidak cukup hanya mempertimbangkan kompleksitas dan ketidaklengkapan pendekatan tersebut.

Hambatan didaktis akan berhubungan pada cara guru menyusun situasi didaktis atas suatu materi pembelajaran. Contohnya dikemukakan oleh Brousseau (2002) dan Cortina, Visnovska \& Zúñiga (2014) mengenai pecahan yang mengemukakan bahwa pendekatan didaktis dengan menggunakan ekuipartisi (equipartition) dalam pecahan dapat menjadi sumber hambatan bagi siswa. Pendekatan ekuipartisi ini membentuk pemahaman siswa bahwa pecahan hanya berhubungan dengan objek-objek yang dapat dipartisi. Akibatnya siswa akan sulit menyelesaikan permasalahan mengenai pecahan jika tidak berhubungan dengan benda tertentu yang dapat dibagi (contoh mengenai ketebalan kertas).

Identifikasi adanya hambatan didaktis dapat dilakukan melalui analisis kesalahan dan kesulitan siswa. Kesalahan dan kesulitan siswa dalam menyelesaikan permasalahan matematis merupakan tanda adanya hambatan belajar (Cornu, 1991; Brousseau, 2002; Manno, 2005; Moru, 2007; Brown, 2008; Nyikahadzoyi, 2013). Dikatakan sebagai hambatan didaktis ketika metafora, representasi dan sumber belajar yang diperkenalkan oleh guru menghasilkan ide-ide matematika yang tidak konsisten dalam tujuan pembelajaran matematika yang lebih kompleks (Cortina, Visnovska \& Zúñiga, 2014). Metafora, analogi dan representasi serta sumber belajar ini dapat ditemukan dalam buku pegangan guru, rencana pembelajaran, contoh soal serta media yang digunakan guru bahkan cara mengetahui guru itu sendiri ketika menghadapi permasalahan yang sama (Bingolbali, Akkoç, Ozmantar \& 
Demir, 2011). Metafora dan representasi ini akan membentuk cara mengetahui siswa.

Penelitian ini bertujuan untuk menguji dan akan mengungkapkan pemahaman dan hambatan yang terbentuk karena pilihan didaktis guru pada pembelajaran pertidaksamaan kuadrat. Analisis hambatan didaktis akan menjadi referensi yang penting bagi guru sehingga dapat menghindari pilihan pendekatan yang tampaknya sederhana dan lengkap tetapi menuntun pada suatu hambatan.

\section{Metode}

Penelitian menggunakan pendekatan kualitatif dengan paradigma interpretif dalam kerangka penelitian desain didaktis. Paradigma interpretif digunakan karena penelitian ini ingin mengetahui persepsi dan pengalaman partisipan. Sementara kerangka penelitain desain didaktis memungkinkan peneliti untuk melihat persepsi dan pengalaman partisipan dalam konteks desain didaktis. Penelitian ini merupakan studi awal dalam penelitian desain didaktis (Suryadi, 2013). Penelitian ini dilakukan pada 105 siswa kelas IX pada salah satu Sekolah Menengah Atas di Bandung. Partisipan adalah siswa yang telah (baru saja) belajar mengenai pertidaksamaan kuadrat dan guru matematika yang mengajar siswa tersebut. Partisipan memiliki karateristik yang setara dalam hal kemampuan matematisnya, gender dan latar belakang sosialekonomi.

Setiap partisipan siswa diberikan tes mengenai konsep pertidaksamaan kuadrat. Tes ini disusun berdasarkan kurikulum pertidaksamaan kuadrat digunakan di sekolah. Terdapat tiga permasalahan yang diberikan pada partisipan. Ketiga permasalahan menuntut kemampuan prosedural maupun konseptual. Secara khusus, ketiga permasalahan menuntut pendekatan penyelesaian yang berbeda-beda (seperti pendekatan sign chart, logical connections, pendekatan fungsi). Tes ini digunakan untuk melihat hambatan berupa cara mengetahui (ways of knowing) partisipan dalam menyelesaikan permasalahan pertidaksamaan kuadrat. Berikut soal tes yang diberikan.

Soal 1.

Perhatikan grafik di bawah ini. Berdasarkan grafik tersebut, tentukanlah nilai $x$ yang memenuhi $x^{2}-2 x-3 \geq 0$.

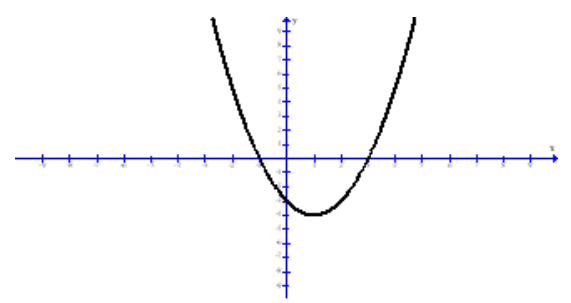


Soal 2.

Tentukanlah himpunan penyelesaian dari:
a. $(x-3)(x+5)>0$
b. $(x-2)(x+4)<7$
c. $x^{2}-2 x+6>0$
d. $-x^{2}+4 x-5 \geq 0$

Tes ini telah divalidasi oleh dua orang dosen pendidikan matematika dan satu orang guru sekolah tempat penelitian.

Berdasarkan hasil analisis tes, beberapa partisipan akan diwawancara guna menggali cara mengetahui siswa dalam menyelesaikan permasalahan pertidaksamaan kuadrat. Pemilihan partisipan untuk wawancara dilakukan berdasarkan hasil tes, misalnya dipilih salah satu siswa yang melakukan kesalahan yang sama. Sementara partisipan guru akan diberikan wawancara yang mendalam mengenai pilihan didaktis yang digunakan. Buku pegangan yang digunakan guru juga akan didokumentasikan untuk memperdalam dan melengkapi data hasil wawancara guru.

\section{Hasil dan Pembahasan}

Hasil penelitian ini dibagi dalam dua bagian. Pada bagian pertama, akan ditampilkan hasil analisis deskripsi pendekatan didaktis pertidaksamaan kuadrat yang digunakan guru melalui analisis teks maupun melalui wawancara dengan guru tersebut. Sedangkan bagian kedua, menampilkan hasil analisis kesalahan-kesalahan siswa dalam mengerjakan permasalahan pertidaksamaan kuadrat.

\section{Pendekatan didaktis dan metafora yang digunakan}

Guru menggunakan tiga buku pegangan dalam mengajar pertidaksamaan kuadrat. Dari ketiga analisis buku pegangan (lihat tabel 1) terlihat secara umum pendekatan yang digunakan adalah garis bilangan (buku pertama, kedua dan ketiga) dan logical connective (buku ketiga).

Tabel 1. Pendekatan didaktis dan metofora buku pegangan

\begin{tabular}{|c|c|c|}
\hline Buku pegangan & Pendekatan didaktis & Metafora \\
\hline Pertama & $\begin{array}{l}\text { Melihat pertidaksamaan sebagai persamaan } \\
\text { kuadrat dengan tanda yang berbeda. Metode } \\
\text { penyelesaian dengan diagram garis bilangan }\end{array}$ & Pembuat nol \\
\hline Kedua & $\begin{array}{l}\text { Melihat pertidaksamaan sebagai persamaan } \\
\text { kuadrat dengan tanda yang berbeda. Metode } \\
\text { penyelesaian dengan diagram garis bilangan }\end{array}$ & Pembuat nol \\
\hline Ketiga & $\begin{array}{l}\text { Melihat pertidaksamaan sebagai persamaan } \\
\text { kuadrat dengan tanda yang berbeda. }\end{array}$ & Pembuat nol \\
\hline
\end{tabular}




\begin{tabular}{lll}
\hline Buku pegangan & \multicolumn{1}{c}{ Pendekatan didaktis } & Metafora \\
\hline & Menghubungkan dengan pertidaksamaan linear. & \\
& $\begin{array}{l}\text { Metode penyelesaian dengan diagram garis } \\
\text { bilagnan dan logical connective. }\end{array}$
\end{tabular}

Pendekatan fungsi dan grafiknya serta pendekatan spreadsheet modelling tidak digunakan. Gambar 1 menunjukkan pendekatan yang digunakan dalam buku ini lebih mengarah pada generalisasi konsep persamaan kuadrat pada pertidaksamaan kuadrat. Artinya, pertidaksamaan dilihat sebagai seolah-olah persamaan kuadrat, dengan tanda yang berbeda. Pertidaksamaan kuadrat menggunakan tanda " $\leq$ ", " $\geq$ ", "<" dan" > ", persamaan kuadrat "=". Namun secara konsep dan prosedur dianggap sama.

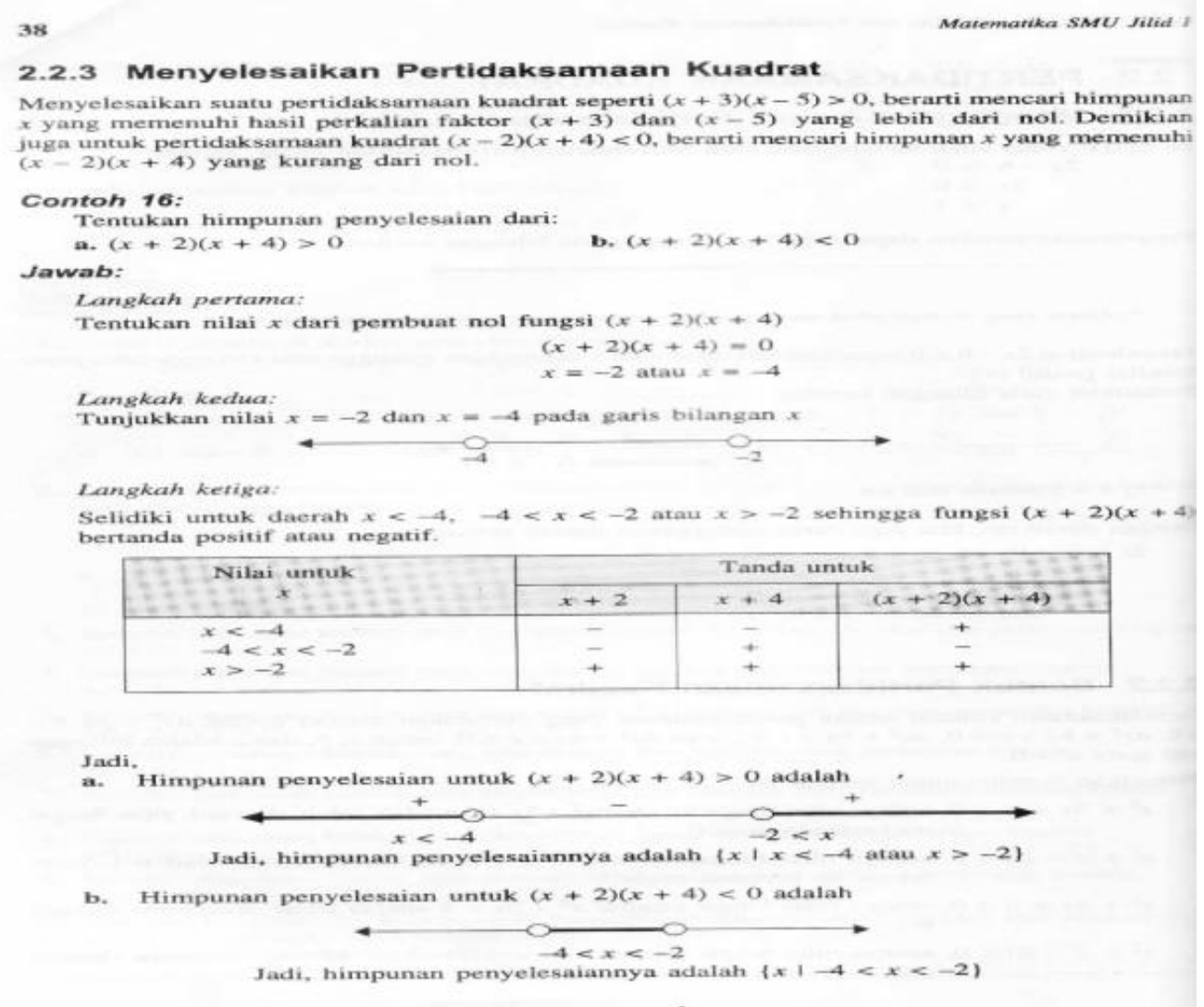

Gambar 1. Contoh pendekatan didaktis pertidaksamaan kuadrat pada buku

Dalam pembelajaran, guru mengikuti pendekatan yang digunakan pada ketiga buku pegangan. Namun guru tidak memperkenalkan penggunaan logical connective pada siswa (lihat wawancara di bawah ini). Pendekatan yang dirujuk guru dari ketiga buku ini adalah pendekatan diagram garis bilangan, khususnya mengenai transformasi pertidaksamaan kuadrat ke persamaan kuadrat sebelum mengambil solusi. Guru mengajarkan pada siswa bahwa 
pertidaksamaan kuadrat mirip bahkan sama dengan persamaan kuadrat, hanya yang berbeda adalah tanda yang digunakan.

Peneliti: Nah ini Bu, saya mau tanya sebelumnya bagaimana ibu
mengajarkan pertidaksamaan kuadrat?
Guru: Cara mengajarkannya. Pertama-tama saya perkenalkan dulu
dengan si pertidaksamaannya dulu, walaupun memang mereka
sudah pernah tahu tentang hal itu. Saya kasih tahu dulu bagaimana
kegunaan pertidaksamaan kuadrat, apa, apa ya. Hm, kalau
pertidaksamaan itu apa perbedaanya dengan persamaan, seperti itu
lah kira-kira. Nah, kalau untuk pertidaksamaan kuadrat seperti
biasa saya buat seolah-oleh dia jadi seperti persamaan kuadrat dulu.
Lalu saya cari $x_{1}, x_{2}-$ nya, itu menjadi batas. Seperti itu. Terus saya
buat titik uji kan, seperti itu, nanti akan kita tahu daerahnya mana
yang positif, negatif. Nah seperti itu, kita akan coba lihat daerah
yang kita inginkan yang mana. Kira-kira seperti itu Pak.

Dari hasil wawancara di atas menunjukkan bahwa pendekatan didaktis yang digunakan guru mendorong siswa untuk melihat pertidaksamaan kuadrat seolah-olah sebagai persamaan kuadrat. "Membuat pertidaksamaan kuadrat menjadi seolah-olah persamaan kuadrat" adalah metafora yang digunakan guru untuk mendorong siswa menggunakan cara mengetahui siswa dalam menyelesaikan pertidaksamaan kuadrat. Metafora lain adalah "batas". Guru menyebut nilai pembuat nol, $x_{1}$ dan $x_{2}$, sebagai batas. Nilai batas ini membagi garis bilangan menjadi tiga bagian, dimana setiap bagian akan diuji apakah bertanda negatif atau positif. Dengan kata lain, metafora "batas" adalah bentuk penggunaan pengetahuan persamaan kuadrat untuk menyelesaikan pertidaksamaan kuadrat.

\section{Kesulitan dan hambatan siswa}

Hasil analisis atas jawaban siswa diperoleh beberapa kesulitan dan hambatan yang muncul. Tabel 2 merupakan ringkasan kesulitan dan hambatan yang dialami siswa.

Tabel 2. Kesulitan dan hambatan yang dialami siswa

\begin{tabular}{llll}
\hline Hambatan dan kesulitan & Karateristik & Frek. $(\%)$ \\
\hline Generalisasi cara & a. & Ketika nilai pembuat nol tidak & $35(33.3 \%)$ \\
mengetahui (ways of & & ditemukan maka siswa menyimpulkan & \\
knowing) persamaan & & pertidaksamaan kuadrat tidak memiliki & \\
kuadrat dalam & & solusi & \\
menyelesaikan & b. & $\begin{array}{l}\text { Pemahaman yang tidak tepat akan } \\
\text { makna semantik dan simbolik dari }\end{array}$ & \\
pertidaksamaan kuadrat & & pertidaksamaan & \\
& &
\end{tabular}




\begin{tabular}{llc}
\hline Hambatan dan kesulitan & Karateristik & Frek. (\%) \\
\hline & $\begin{array}{l}\text { c. } \quad \begin{array}{l}\text { Membagi dan mengalikan dengan } \\
\text { faktor non positif tanpa mengganti } \\
\text { tanda pertidaksamaan }\end{array} \\
\text { Rendahnya pengetahuan mengenai kata } \\
\text { penghubung logika (logical connection) }\end{array}$ & $24(23 \%)$ \\
$\begin{array}{l}\text { Pendekatan yang } \\
\text { digunakan siswa terbatas }\end{array}$ & $\begin{array}{l}\text { Siswa tidak mengetahui hubungan dari } \\
\text { berbagai representasi pertidaksamaan } \\
\text { kuadrat (grafik, fungsi) }\end{array}$ & \\
\hline
\end{tabular}

Kesulitan dan hambatan ini dapat dikelompokkan menjadi dua. Pertama, generalisasi cara mengetahui persamaan kuadrat ke pertidaksamaan kuadrat. Dengan kata lain, siswa menggunakan cara mengetahui dan cara berpikir atas persamaan kuadrat dalam menyelesaikan pertidaksamaan kuadrat. Hal itu terlihat dari jawaban siswa atas soal nomor 2a pada gambar 2.
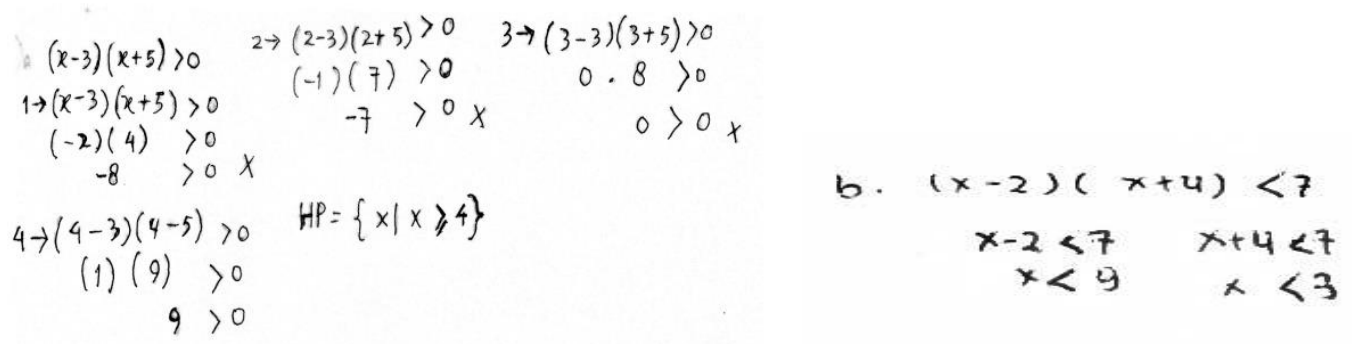

Gambar 2. Jawaban siswa atas soal ketiga dan no $2 b$

Gambar 2 menunjukkan generalisasi cara mengetahui; pemahaman persamaan kuadrat ke pertidaksamaan kuadrat. Pada persamaan kuadrat ketika $\mathrm{x}=$ a memenuhi $\mathrm{f}(\mathrm{x})=0$ maka solusi dapat diambil $\mathrm{x}=\mathrm{a}$, namun dalam pertidaksamaan kuadrat ketika solusi $x=$ a memenuhi $f(x)>0$ belum tentu solusi $x>0$. Hal ini diperkuat oleh wawancara di bawah ini.

Peneliti: Kalau nomor 3, dari mana $x=1, x=3$ atau $x=4$ ?

Siswa : Ini saya masukin-masukin, nyoba-nyoba pak

Peneliti: Ngak memfaktorkan?

Siswa : Ini, ngak

Peneliti: Misalnya kalau udah kamu coba neh, $x=4$, benar? Jadi ini kenapa gini $x \geq 4$

Siswa : x lebih besar sama dengan 4 itu kan, berarti ini memenuhi sama soalnya ini pak, $(x-3)(x+5)>0$, pada saat $x$ itu 4 memenuhi lebih 0 .

Peneliti: Kan 4 aja yang kamu coba, kenapa langsung kamu buat lebih besar dari 4 .

Siswa : Soalnya pasti ke atasnya pasti lebih besar, pasti positif

Peneliti: Memenuhi gitu?

Siswa : Iya Pak

Siswa melihat ketika nilai yang dipilih sudah memenuhi sebagai pembuat nol maka tinggal membubuhkan tanda pertidaksamaan kuadrat. Ini 
menunjukkan pemahaman yang tidak tepat akan makna semantik dan simbolik dari pertidaksamaan. Siswa menyamakan makna tanda pertidaksamaan dengan persamaan. Selain itu, hal ini menunjukkan pedoman siswa dalam menentukan penyelesaian pertidaksamaan adalah nilai pembuat nol. Untuk menyelesaikan pertidaksamaan kuadrat maka pembuat nol harus ditentukan. Kesulitan lain yang muncul adalah rendahnya pengetahuan mengenai kata penghubung logika (logical connection) dimana siswa melakukan generalisasi persamaan kuadrat terhadap pertidaksamaan kuadrat. Hal ini terlihat ketika siswa mentransformasi $(x-5)(x+3) \geq 0$ menjadi $x \geq 5$ dan $x \geq-3$. Jawaban ini juga terjadi karena siswa tidak menggunakan logika perkalian dalam menyelesaian pertidaksamaan tersebut, sehingga siswa tidak melihat bahwa $x \leq 5$ dan $x \leq-3$ juga memenuhi.

Sementara ketika menyelesaikan permasalahan $2 b$, dari $(x-2)(x+4)<7$ siswa memperoleh pembuat nol dari pertidaksamaan tersebut adalah $x=2$ dan $x=-$ 4. Hal ini terjadi karena siswa tidak memahami sifat pertidaksamaan, sehingga siswa melakukan generalisasi dari $(x-2)(x+4)<0$. Kesalahan siswa ini bisa terjadi jika siswa diajarkan sebatas prosedural saja tidak menggunakan logical connection (gambar 2). Selain bentuk jawaban di atas, kesalahan lain karena siswa dalam menyelesaikan permasalahan $2 b$ adalah mengubah $(x-$ $2)(x+4)<7$ menjadi $(x-2)=7$ atau $(x+4)=7$. Dalam hal ini siswa mengikuti prosedur $(x-2)(x+4)=0$ menjadi $(x-2)=0$ atau $(x+4)=0$.

Kedua, kesulitan dan hambatan karena pendekatan yang digunakan oleh siswa terbatas. Siswa hanya menggunakan pendekatan garis bilangan untuk menyelesaikan semua permasalahan. Semua siswa menggunakan pendekatan ini dalam menyelesaikan semua permasalahan pertidaksamaan kuadrat, bahkan meskipun grafik fungsi $y=f(x)$ diberikan. Dalam menjawab problem 1 , siswa tetap menggunakan pendekatan diagram garis bilangan meskipun grafik fungsi $y=x^{2}-2 x-3$ diberikan. Siswa terpaku pada penentuan pembuat nol sebagai langkah awal dalam menyelesaikan pertidaksamaan kuadrat (lihat gambar 3).
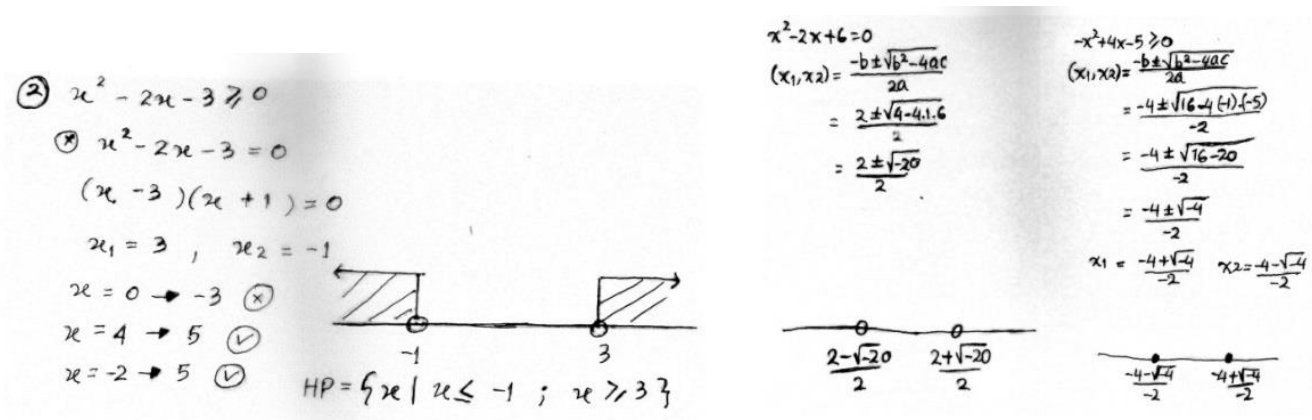

Gambar 3. Jawaban siswa atas soal no 1, 2c dan 2d 
Kesulitan yang dihadapi oleh hampir semua siswa ketika menggunakan pendekatan ini adalah menyelesaikan pertidaksamaan kuadrat yang bernilai benar untuk $\forall x \in R$. Hal ini terlihat ketika siswa menyelesaikan permasalahan $2 \mathrm{c}$ dan $2 \mathrm{~d}$. Untuk menyelesaikan soal $2 \mathrm{c}$ dan $2 \mathrm{~d}$, siswa menggunakan pendekatan diagram garis bilangan dengan mentransformasi pertidaksamaan kuadrat ke persamaan kuadrat terlebih dahulu. Transformasi ini dilakukan dengan mengganti tanda pertidaksamaan menjadi persamaan kuadrat. Kemudian siswa mencari pembuat nol dari persamaan kuadrat ini (lihat gambar 3). Penentuan pembuat nol dilakukan dengan menggunakan rumus $a b c$. Siswa menggunakan rumus ini karena kesulitan menggunakan pendekatan pemfaktoran.

Siswa melihat bahwa ketika pembuat nol tidak ditemukan maka pertidaksamaan tersebut tidak memiliki penyelesaian. Padahal kedua pertidaksamaan tersebut bernilai benar untuk semua nilai $\forall x \in R$. Artinya meskipun tidak ada $x$ yang memenuhi $x^{2}-2 x+6=0$ dan $-x^{2} 4 x-5=0$, kedua pertidaksamaan tersebut memiliki solusi. Dengan kata lain, pengetahuan siswa telah terbentuk bahwa ketika pembuat nol tidak ada (atau tidak ada nilai $x$ yang memenuhi $f(x)=0$ ) maka pertidaksamaan kuadrat tersebut tidak memiliki solusi. Hal ini sesuai dengan pemahamannya mengenai persamaan kuadrat, bahwa persamaan kuadrat memiliki solusi jika pembuat nol dapat ditentukan (lihat wawancara di bawah).

Peneliti : Kalau ini (nomor 2c, 2d) kenapa kamu pakai rumus abc (berbeda ketika mengerjakan soal sebelumnya)?

Siswa : Soalnya nggak bisa difaktorin, jadi harus pakai rumus abc.

Peneliti : Ada hasilnya?

Siswa : Tapi ngak ada hasilnya, karna akar minus ngak bisa dihitung

\section{Kesesuaian Pendekatan Didaktis dan Metafora dengan Kesulitan dan} hambatan siswa

Pemaparan di atas menunjukkan bahwa cara mengetahui yang dikembangkan oleh siswa selaras dengan pilihan pendekatan didaktis yang diambil guru. Pendekatan didaktis yang digunakan guru dalam pembelajaran pertidaksamaan kuadrat adalah pendekatan diagram garis bilangan, penggunaan metafora "batas" dan "seolah-olah sama dengan persamaan kuadrat". Pilihan-pilihan ini didasarkan pada konsep pembuat nol sebagai langkah pertama dalam menentukan solusi pertidaksamaan kuadrat. Akibat pendekatan ini, terbentuk cara mengetahui siswa mengenai pertidaksamaan kuadrat berupa i) solusi pertidaksamaan kuadrat ditentukan ada atau tidaknya pembuat nol; ii) pertidaksamaan kuadrat adalah persamaan kuadrat yang tandanya bukan "=". 
Pembuat nol merupakan konsekuensi dari pilihan pendekatan diagram garis bilangan yang digunakan guru. Langkah utama yang guru tekankan ketika menggunakan diagram garis bilangan adalah penentuan pembuat nol. Implikasinya, ketika menghadapi pertidaksamaan kuadrat dimana tidak ada nilai $x$ yang memenuhi agar fungsi $f(x)$ bernilai 0 , siswa menyimpulkan bahwa pertidaksamaan kuadrat tersebut tidak memiliki solusi. Bahkan ketika grafik fungsi $f(x)$ sudah diberikan, siswa tetap mencari pembuat nol dari pertidaksamaan kuadrat. Cara mengetahui atau pemahaman ini tepat dan efektif ketika mengehadapi permasalahan pertidaksamaan kuadrat $f(x)<$ $0, f(x)>0, f(x) \leq 0$ atau $f(x) \geq 0$ dimana $\exists x \in R, f(x)=0$. Sebaliknya, dengan cara mengetahui atau pemahaman yang seperti itu, siswa mengalami hambatan ketika menghadapi pertidaksamaan kuadrat yang memiliki solusi $\{x \mid \forall x \in R\}$. Dengan demikian, pembuat nol merupakan hambatan didaktis yang terjadi pada pertidaksamaan kuadrat.

Ada dua temuan dari penelitian ini. Pertama, pilihan didaktis guru bersesuaian dengan cara mengetahui siswa dan menimbulkan kesulitan serta hambatan belajar. Pilihan didaktis guru yang hanya menggunakan pendekatan garis bilangan dengan gagasan pembuat nol selaras dengan cara mengetahui dan pemahaman siswa dalam menyelesaikan permasalahan pertidaksamaan kuadrat. Siswa melihat pertidaksamaan kuadrat sebagai persamaan kuadrat dengan tanda yang berbeda. Hal ini sesuai dengan teori belajar yang mengungkapkan bahwa siswa belajar melalui interaksi atas milieu atau lingkungan belajar (Brousseau, 1997). Hasil interaksi ini akan membentuk cara mengetahui siswa. Bentuk cara mengetahui sangat dipengaruhi oleh milieu (lingkungan belajar) yang dihadapi oleh siswa. Biasanya dalam berbagai pendekatan pembelajaran, bentuk milieu ini diinisiasi oleh guru.

Kedua, pendekatan tunggal garis bilangan yang didasarkan pada metafora pembuat nol dari persamaan kuadrat merupakan bentuk hambatan didaktis. Hasil di atas menunjukkan bahwa kesulitan dan hambatan yang dialami oleh siswa bukanlah ketidaktahuannya. Hal ini terlihat bahwa semua siswa punya gagasan atau ide untuk menyelesaikan pertidaksamaan kuadrat. Gagasan atau ide ini bukan sesuatu yang salah, tetapi tidak tepat untuk semua konteks. Misalnya, transformasi dari $(x-5)(x+3) \geq 0$ menjadi $(x-5) \geq 0$ dan $(x-5) \geq 0$ bukan tidak tepat. Masalahnya transformasi ini tidak lengkap dan digunakan untuk semua kasus. Tidak lengkap karena $(x-5)(x+3) \geq 0$ dapat ditransformasi menjadi $(x-5) \leq 0$ dan $(x+3) \leq 0$. Digunakan untuk semua kasus karena model ini digunakan untuk kasus lain yaitu mentransformasi $(x-5)(x+3) \leq 0$ menjadi $(x-$ 
$5) \leq 0$ dan $(x+3) \leq 0$. Hal ini menunjukkan cara mengetahui dan pemahaman siswa pada persamaan kuadrat digunakan pada permasalahan pertidaksamaan kuadrat. Cara mengetahui ini berupa gagasan atau metafora pembuat nol. Hal ini sesuai dengan kriteria hambatan didaktis yang diungkapkan oleh Brousseau (1997) bahwa hambatan didaktis, hambatan yang terbentuk karena pilihan pendekatan yang diambil guru. Hal yang sama diungkapkan oleh Cortina, Visnovska, \& Zúñiga (2014) yang mengungkapkan bahwa hambatan didaktis terjadi ketika metafora, representasi dan sumbersumber belajar yang diperkenalkan oleh guru menghasilkan ide-ide matematika yang tidak konsisten dalam tujuan pembelajaran matematika yang lebih kompleks.

Dalam penelitian ini, metafora dan gagasan pembuat nol tidak konsisten untuk semua kasus persamaan kuadrat. Dari temuan ini juga terlihat aspek hambatan didaktis yang lain. Yaitu pilihan didaktis yang sederhana belum tentu membantu pemahaman siswa. Guru menganggap bahwa pilihan diagram garis bilangan dengan ide pembuat nol nya adalah pendekatan dan metafora yang sederhana. Namun nyatanya menimbulkan kesulitan dan

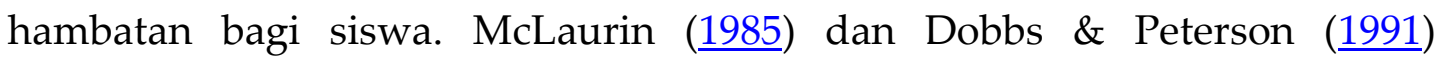
mengungkapkan bahwa pendekatan diagram garis bilangan, dengan ide utama pembuat nol-nya, adalah metode yang paling bagus karena kesederhanaan dan dapat digunakan pada semua bentuk pertidaksamaan.

Namun, pandangan McLaurin (1985) dan Dobbs \& Peterson (1991) tersebut tidak didasarkan pada penelitian (Tsamir \& Reshef, 2006). Fakta empiris yang ditemukan melalui penelitian ini malah mengungkapkan hal yang berbeda. Siswa mengalami hambatan ketika menggunakan pendekatan ini. Bahkan, siswa hanya memaknai pertidaksamaan kuadrat secara prosedural belaka (Kieran, 2004). Buktinya, meskipun grafik fungsi $f(x)$ telah diberikan atau bahkan ketika diminta untuk digambarkan sendiri oleh siswa, penyelesaian pertidaksamaan kuadrat yang melibatkan $f(x)$ tetap menggunakan diagram garis bilangan. Hasil penelitian ini mengklarifikasi fenomena yang sering kali pemilihan pendekatan didaktis didasarkan pada intuisi guru mengenai kompleksitas dan kelengkapan informasi yang diberikannya. Padahal pendekatan didaktis yang dianggap paling sederhana baik secara prosedur maupun secara metafora dapat menuntun pada terjadinya hambatan belajar.

Hasil penelitian ini konsisten dengan penelitian terdahulu. Dimana kesulitan yang dialami oleh siswa dalam menyelesaikan pertidaksamaan kuadrat menyangkut pemahaman yang tidak tepat akan makna semantik dan simbolik dari pertidaksamaan, rendahnya pengetahuan mengenai kata 
penghubung logika (logical connection), membagi dan mengalikan dengan faktor non positif tanpa mengganti tanda pertidaksamaan (Tsamir and Bazzini, 2004; Blanco, 2007; Çiltaş \& Tatar, 2011; Bicer, Capraro \& Capraro, 2014; Makonye \& Nhlanhla, 2014; Makonye \& Shingirayi, 2014; Yin, 2015; Mananggel, 2020). Penelitian ini memperkaya dan memberikan wawasan baru pada penelitian terdahulu dalam dua hal. Pertama, penelitian ini memberikan informasi dampak pendekatan yang digunakan oleh guru terhadap cara mengetahui dan pemahaman siswa. Penelitian ini memberikan informasi kesejajaran pendekatan didaktis yang digunakan oleh guru dengan cara mengetahui siswa. Kesejajaran ini, sesuai dengan teori belajar, menunjukkan sumber kesulitan yang dialami siswa. Sumber kesulitan ini adalah pilihan didaktis guru.

Kedua, implikasi epistemologis dari pilihan pendekatan didaktis. Pendekatan didaktis tertentu tidak hanya sekadar menimbulkan kesulitan atau kesalahan ketika menghadapi permasalahan pertidaksamaan kuadrat. Pedekatan tersebut akan membentuk struktur epistemologis (berupa cara mengetahui) yang tidak lengkap dan bermasalah. Misalnya, pendekatan diagram garis bilangan dengan gagasan pembuat nol akan membentuk pemahaman dan cara mengetahui bahwa pertidaksamaan kuadrat memiliki solusi jika pembuat nol dapat ditemukan. Hal ini sifatnya epistemologis (Brousseau, 1997). Dengan demikian, secara epistemologis pertidaksamaan kuadrat bergantung pada persamaan kuadrat. Akibatnya, struktur epistemologis ini akan menjadi hambatan pada pembelajaran lanjutan.

Meskipun dalam soal diberikan permasalahan yang memungkinkan menggali penerapan semua pendekatan namun penelitian ini tidak memberikan informasi untuk semua pendekatan. Penelitian ini hanya melihat pendekatan yang digunakan oleh guru sejajar dengan cara memahami dan cara berpikir siswa. Untuk itu perlu penelitian lebih lanjut untuk melihat apakah pendekatan lain juga menimbulkan hambatan didaktis.

Untuk itu guru perlu berhati-hati menggunakan pendekatan diagram garis bilangan dan metafora pembuat nol/batas. Penggunaan satu pendekatan tunggal juga memungkinkan terjadinya hambatan, sebagaimana yang dialami siswa dalam penelitian ini. Solusi dalam mengatasi hambatan ini adalah penggunaaan berbagai pendekatan didaktis dalam pertidaksamaan kuadrat (Tsamir dan Reshef, 2006; Mahmood \& Al-Mirbati, 2017). Namun, perlu diatur lintasan belajar yang dilalui, mengatur urutan pendekatan yang digunakan, siswa sehingga penggunaan berbagai pendekatan tidak malah

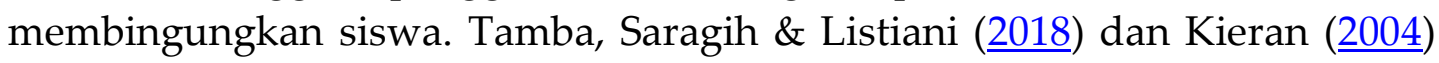


menyarankan suatu lintasan belajar yang dimulai dari konseptual ke prosedural, yaitu dimulai dari pendekatan fungsi dan diakhiri dengan pendekatan diagram garis bilangan.

\section{Simpulan}

Temuan dan diskusi di atas menunjukkan adanya hambatan didaktis yang dialami oleh siswa dalam pembelajaran pertidaksamaan kuadrat. Hambatan didaktis tersebut adalah penggunaan metafora pembuat nol sebagai konsep kunci dalam menyelesaikan pertidaksamaan kuadrat. Pembuat nol adalah semua nilai $x$ yang memenuhi sehingga $f(x)=0$. Pembuat nol merupakan konsep dari persamaan kuadrat yang digunakan dalam menyelesaikan pertidaksamaan kuadrat. Dengan kata lain, penggunaan metafora ini mengkondisikan siswa untuk menggunakan cara mengetahui dan pemahaman persamaan kuadrat untuk memahami pertidaksamaan kuadrat. Dimana ketika pembuat nol tidak ditemukan, siswa menyimpulkan bahwa pertidaksamaan kuadrat tidak memiliki solusi. Padahal tidak didalam semua kondisi hal ini berlaku.

\section{Daftar Pustaka}

Abramovich, S. (2005). Spreadsheet modeling as a didactical framework for inequality-based reduction. International Journal of Mathematical Education in Science and Technology, 37 (5), 527-541.

Almog, N., \& Ilany, B.S. (2012). Absolute value inequalities: high school students' solutions and misconceptions. Educational Studies in Mathematics, 81(3), 347-364.

Bazzini, L. dan Tsamir, P. (2001). Research-based instruction: widening students' perspective when dealing with inequality. Proceedings of the 12th ICMI Study The Future of Teaching and Learning of Algebra, 61-68. The University of Melbourne, Melbourne.

Bicer, A., Capraro, R.M., \& Capraro, M. M. (2014). Pre-service teacher's linear and quadratic inequality understanding. International Journal for Mathematics Teaching and Learning, 15(1), 1-10.

Bingolbali, E., Akkoç, H., Ozmantar, M. F., \& Demir, S. (2011). Pre-service and in-service teachers' views of the sources of students' mathematical difficulties. International Electronic Journal of Mathematics Education, 6(1), 40-59.

Blanco, L. J., \& Garrote, M. (2007). Difficulties in learning inequalities in students of the first year of pre-university education in Spain. Eurasia Journal of Mathematics, Science $\mathcal{E}$ Technology Education, 3(3), 221-229.

Brown, S., A. (2008). Exploring epistemological obstacles to the development of mathematics induction. Proceedings of the 11th Conference for Research on Undergraduate Mathematics Education, 1-19.

Brousseau, G. (2002). Theory of Didactical Situation in Mathematics. Dordrecht: Kluwer Academic Publishers.

Çiltaş, A. \& Tatar, E. (2011). Diagnosing Learning Difficulties Related to the Equation and Inequality that Contain Terms with Absolute Value. International Online Journal of Educational Sciences, 3(2), 461-473. 
Cohen, L., Manion, L., \& Morrison, K. (2011). Research methods in education. London: Routledge Falmer.

Cornu B. (2002). Limits. In: Tall D. (Eds.), Advanced Mathematical Thinking. Mathematics Education Library, 11 (153-166) . Springer, Dordrecht.

Cortina, J. L., Visnovska, J., \& Zúñiga, C. (2013). Equipartition is a didactical obstacle in fraction instruction. Acta Didactica Universitatis Comenianae Mathematics, 14(1), 1-18.

Dobbs, D., \& Peterson, J. (1991). The sign-chart method for solving inequalities. The Mathematics Teacher, 84(8), 657-664.

Kemendikbud. (2016). Peraturan menteri pendidikan dan kebudayaan nomor 21 tahun 2016 tentang standar isi pendidikan dasar dan menengah. Jakarta: Kemendikbud.

Kieran, C. (2004). The equation/inequality connection in constructing meaning for inequality situations. In M. J. Høines \& A. B. Fuglestad (Eds.), Proceedings of the 28th Conference of the International Group for the Psychology of Mathematics Education, 143-127. Bergen, Norway: Bergen University College.

Linchevski, L., \& Sfard, A. (1991). Rules without reasons as processes without objects - the case of equations and inequalities. Proceedings of PME15, 2, 317-324, Assisi, Italy.

Mahmood, M., \& Al-Mirbati, R. (2017). An algebraic approach for solving quadratic inequalities. Australian Senior Mathematics Journal, 31(2), 31-41.

Makonye, J., \& Shingirayi, M. (2014). The obstacles faced by the learners in the learning of quadratic inequalities. Mediterranean Journal of Social Sciences, 5(27), 716-725.

Makonye, J., \& Nhlanhla, S. (2014). Exploring "non-science" grade 11 learners' errors in solving quadratic equations. Mediterranean Journal of Social Sciences, 5(27), 634-644.

Mananggel, M. (2020). Diagnosis of students difficulties in solving word problem related to the quadratic innequalities using mapping mathematics. JUPITEK: Jurnal Pendidikan Matematika, 2(2), 61-68.

Manno, G. (2005). Embodiment and a-didactical situation in the teaching-learning of the perpendicular straight lines concept. Unpublished Thesis. Palermo: Unipa.

McLaurin, S. (1985). A unified way to teach the solution of inequalities. The Mathematics Teacher, 78(2), 91-95.

Moru, E. (2007). Talking with the literature on epistemological obstacles. For the Learning of Mathematics, 27(3), 34-37.

NCTM. (2000). Principles and Standard for School Mathematics. Reston Virginia: The National Council of Mathematics of Teacher of Mathematics, Inc.

Nyikahadzoyi, M. R., Mapuwei, T., \& Chinyoka, M. (2013). Some cognitive obstacles faced by ' $a$ ' level mathematics students in understanding inequalities: a case study of bindura urban high schools. International Journal of Academic Research in Progressive Education and Development, 2(2), 2226-6348.

Sackur, K. (2004). Problems related to the use of graphs in solving inequalities. Proceedings of the 28th Conference of the International Group of Psychology of Mathematics Education, Bergen, Norway, 1, 148-152.

Suryadi, D. (2013). Didactical Design Research (DDR) dalam pengembangan pembelajaran matematika. Prosiding Seminar Nasional Matematika dan Pendidikan Matematika. Bandung, Indonesia: STKIP Siliwangi.

Tamba, K. P., Saragih, M. J., \& Listiani, T. (2018). Learning trajectory of quadratic inequality. JOHME: Journal of Holistic Mathematics Education, 2(1), 12-21. DOI:10.19166/johme.v2i1.1202

Tsamir, P., \& Almog, N. (2001). Students' strategies and difficulties: the case of algebraic inequalities. International Journal Of Mathematical Education In Science And Technology, 32(4), 513-524. 
Tsamir, P., \& Bazzini, L. (2004). Consistencies and inconsistencies in students' solutions to algebraic 'single-value' inequalities. International Journal of Mathematical Education in Science and Technology, 35(6), 793-812.

Tsamir, P., \& Reshef, M. (2006). Students' preferences when solving quadratic inequalities. Focus on Learning Problems in Mathematics, 28(1), 37-50.

Ureyen, M., Mahir, N., \& Cetin, N. (2006). The mistakes made by the students taking a calculus course in solving inequalities. Electronic International Journal for Mathematics Teaching and Learning, 7(1), 1-6.

Yin, L.Y. (2005). Understanding student"s quadratic inequality misconception through an indepth interview. Third International Qualitative Research Convention 2005. Qualitative Research Experience Across Discipline, Universiti Teknologi Malaysia \& Qualitative Research Association of Malaysia, Johor, Malaysia. 